\title{
Prospective Comparative Randomized Controlled Study to Determine the Optimal Priming Dose of Atracurium
}

\author{
Arun Kumar Handigodu Duggappa, Shaji Mathew, Abhishek Rao Kordcal, Arun Chakravarthi, Shiyad Muhamed \\ Department of Anaesthesiology, Kasturba Medical College, Manipal, Karnataka, India
}

\section{Abstract}

Introduction: The advantages of the use of muscle relaxants in the current practice of balanced anesthesia are well documented. Most often, nondepolarizing muscle relaxants (NDMR) with minimal side effects are used to serve the purpose. Atracurium is a commonly used NDMR in day-to-day anesthetic practice, although it is not desirable for rapid sequence induction and intubation due to its late onset of action. To overcome this problem priming principle was introduced. Aim: This study aims to determine optimal priming dose of atracurium to speed up the onset of action. Patients and Methods: In this prospective randomized controlled study, 90 patients were allocated into one of the three groups by a computer-generated table of random numbers, i.e., Group A, B, and C. Total dose of atracurium used in all patients was $0.5 \mathrm{mg} / \mathrm{kg}$ body weight, including the priming dose. Each group received different priming doses of atracurium as follows: Group A received $0.05 \mathrm{mg} / \mathrm{kg}$ body weight, Group B received $0.025 \mathrm{mg} / \mathrm{kg}$ body weight, whereas Group C (control) received saline as priming dose. Results: Patients were comparable with respect to demographic data. The mean duration in seconds for train-of-four (TOF) count to reach zero were $147 \mathrm{~s}$, 193 , and $218 \mathrm{~s}$ in Group A, B, and C, respectively, with statistically significant $P$ values. Of 60 patients who were administered atracurium as priming drug, two patient had ptosis at the end of $3 \mathrm{~min}$ after priming with $0.05 \mathrm{mg} / \mathrm{kg}$ body weight, with no other side effects. Conclusions: Priming principle employing atracurium reduces the time required for TOF count to reach zero by approximately $71 \mathrm{~s} \mathrm{while} \mathrm{using} 0.05 \mathrm{mg} / \mathrm{kg}$ body weight and by around $25 \mathrm{~s}$ while employing $0.025 \mathrm{mg} / \mathrm{kg}$ body weight, with clinically insignificant incidence of adverse effects.

Keywords: Atracurium, neuromuscular relaxants, priming, train-of-four

\section{INTRODUCTION}

Atracurium, a bisquaternary benzylisoquinolinium, is a nondepolarizing neuromuscular blocking drug. The parent drug and its stereoisomers are commonly used in day-to-day anesthetic practice. Organ independent elimination is an important advantage, thus, it can be used relatively safely in patients with hepatic and renal disease, but its late onset of action is not desirable for rapid sequence induction and intubation. ${ }^{[1,2]}$ Priming principle was introduced in the 1980s to speed up the onset of action of nondepolarizing muscle relaxants (NDMR). This principle refers to administration of a smaller, subparalyzing dose of the drug a few minutes before the intubating dose. ${ }^{[3,4]}$ The administration of the second larger dose at the time of the development of the maximal effect of the priming dose increases the receptor occupancy to over $90 \%$ which is required for profound neuromuscular blockade. ${ }^{[5]}$

The aim of the current study was to determine the optimal priming dose of atracurium with least incidence of adverse

\begin{tabular}{|l|l|}
\hline \multicolumn{2}{|c|}{ Access this article online } \\
\hline Quick Response Code: & Website: \\
\hline & www.ijrconline.org \\
\hline
\end{tabular}

effects of priming. The primary objective was to find out time required for train-of-four (TOF) count to reach zero after intubating dose of atracurium when priming has been employed. Secondary objectives were to look for the incidence of adverse effects of priming with atracurium such as diplopia, ptosis, shortness of breath, motor weakness, and desaturation.

\section{Patients and Methods}

This study was a prospective, comparative randomized clinical trial. After obtaining institutional ethics committee approval, 90 patients of either gender aged 18-60 years belonging to the American Society of Anesthesiologists Physical Status I or II

Address for correspondence: Dr. Shaji Mathew, Department of Anaesthesiology, Kasturba Medical College, Manipal, Karnataka, India. E-mail: shajimanipal@yahoo.co.in

This is an open access article distributed under the terms of the Creative Commons Attribution-NonCommercial-ShareAlike 3.0 License, which allows others to remix, tweak, and build upon the work non-commercially, as long as the author is credited and the new creations are licensed under the identical terms.

For reprints contact: reprints@medknow.com

How to cite this article: Duggappa AK, Mathew S, Kordcal AR, Chakravarthi A, Muhamed S. Prospective comparative randomized controlled study to determine the optimal priming dose of atracurium. Indian J Respir Care 2018;7:42-5. 
Duggappa, et al.: Optimal priming dose of atracurium

with modified Mallampati Class I and II airway, undergoing elective surgery requiring general anesthetic and orotracheal intubation were enrolled.

The patients were randomly allocated (computer-generated randomization table) into three groups of 30 patients (Group A, Group B, and Group C). The exclusion criteria included patients at risk for gastric aspiration, anticipated difficult airway and pregnancy. Patients taking drugs that interfere with neuromuscular function and with electrolyte imbalance/respiratory/neuromuscular disorders were also excluded from this study.

The total dose of atracurium used in all patients was $0.5 \mathrm{mg} / \mathrm{kg}$ body weight, including the priming dose. Each group received different priming doses of atracurium as follows: Group A received $0.05 \mathrm{mg} / \mathrm{kg}$ body weight, Group B received $0.025 \mathrm{mg} / \mathrm{kg}$ body weight, whereas Group C (control) received saline as priming dose.

There were three observers in the study. Observer 1 was the postgraduate in anesthesiology blinded to group allocation, who evaluated the patients preoperatively on the day before surgery and selected patients who met the inclusion criteria, observed and recorded the study parameters. Observer 2 was the consultant anesthesiologist nonblinded to the group allocation who was involved with the preparation of priming dose and intubating dose of study drug and carried out intravenous induction of anesthetic. Observer 3 was an additional consultant nonblinded to group allocation, who carried out preoxygenation, bag-mask ventilation, and intubation.

Preoperative evaluation of the patients was done on the day before surgery and written informed consent obtained. All patients were kept nil per orally for minimum of $2 \mathrm{~h}$ for clear liquids and $6 \mathrm{~h}$ for solid food and premedicated with tablet pantoprazole $40 \mathrm{mg}$ and metoclopramide $10 \mathrm{mg}$ on the morning of day of surgery. Inside the operating room, intravenous access was established and all the patients were monitored with pulse oximetry, noninvasive blood pressure, and 5-lead electrocardiography. A peripheral nerve stimulator (Fisher and Paykel healthcare Ltd, Auckland, New Zealand) capable of delivering TOF stimulus was attached to the dominant hand of the patient to visually monitor thumb adduction by stimulating ulnar nerve at wrist.

Observer 2 loaded the atracurium priming dose as well as intubating dose as per the group allocation and body weight of patients. The atracurium besylate (Artacil, Neon laboratories Ltd, vial containing $25 \mathrm{mg} / 2.5 \mathrm{ml}$ ) was diluted in a $10 \mathrm{ml}$ syringe so as to yield $5 \mathrm{mg} / \mathrm{ml}$. If the patient weighed $>50 \mathrm{~kg}$, two ampoules of atracurium were taken. For finer dilution of drug insulin syringe was used to yield an accuracy up to $25 \mu \mathrm{g}$, which was required for the study. Observer 3 preoxygenated the patients using $100 \%$ oxygen through a tight-fitting facemask for 3 min followed by intravenous administration of priming dose by observer 2 . In patients belonging to Group $\mathrm{C}$ (control group), $10 \mathrm{ml}$ of normal saline was used for priming. Oxygen administration continued for the next $3 \mathrm{~min}$, during which adverse effects related to priming such as diplopia, ptosis (the distance between pupillary center and upper eyelid margin when the patient looks straight ahead), shortness of breath, motor weakness, and desaturation were observed and recorded by Observer 1 at the end of each minute. In the event of desaturation $<92 \%$ any time within 3 min after priming, the patient was provided intravenous induction of the anesthetic and the case excluded from further statistical analysis.

After the completion of 3 min after priming, intravenous induction of the anesthetic was done by Observer 2 using propofol $2 \mathrm{mg} / \mathrm{kg}$, fentanyl $2 \mu \mathrm{g} / \mathrm{kg}$, and intubating dose of atracurium was administered. This was $0.45 \mathrm{mg} / \mathrm{kg}$ in Group A, $0.475 \mathrm{mg} / \mathrm{kg}$ in Group B, and $0.5 \mathrm{mg} / \mathrm{kg}$ in Group C, respectively, thus ensuring that the total dose of atracurium used was $0.5 \mathrm{mg} / \mathrm{kg}$ body weight. After completion of administration of intubating dose of atracurium, Observer 1 switched on the peripheral nerve stimulator (placed to stimulate ulnar nerve of dominant hand at wrist using $40 \mathrm{~mA}$ current strength) to monitor the TOF count by visual means of thumb adduction and also started the timer to record the time $(\mathrm{t})$ from the administration of intubating dose of atracurium till TOF count reached zero. Once the patient went apneic, Observer 3 performed bag-mask ventilation with $100 \%$ oxygen and isoflurane to achieve a minimum alveolar concentration of 1-1.3. After TOF count reached zero, intubation was carried out and surgical procedure begun. Observer 1 was blinded to the group allocation of patients till the completion of the study. It was disclosed once the data were collected and were due for statistical analysis.

\section{Statistical analysis}

For the present study to have a power of $80 \%$, confidence interval of $95 \%$, acceptable Type I error of $5 \%$, a time of $20 \mathrm{~s}$ to be of significance, the sample size required was 30 in each group. All the 90 patients completed the study, with nil dropouts. SPSS version 16.0 (Chicago, SPSS Inc) was used for statistical analysis. Chi-square test and ANOVA were used to analyze the data.

\section{RESULTS}

Patients were comparable with respect to demographic data [Table 1]. ANOVA test was used to compare the mean age, height, weight, and body mass index between groups (with $P$ values being $0.648,0.063,0.072$, and 0.16 , respectively), which revealed no statistical significance. The mean time to achieve a TOF of zero was tested with ANOVA test and statistically significant difference among three groups [Table 2]. A post hoc test (Tukey) was done to compare two groups at a time, which revealed that statistically significant differences in time existed between groups [Table 3]. Of 60 patients who were administered atracurium as priming drug, two patients in Group A had ptosis at the end of $3 \mathrm{~min}$ after priming with $0.05 \mathrm{mg} / \mathrm{kg}$ body weight, with no other side effects [Table 4]. 
Duggappa, et al:: Optimal priming dose of atracurium

\begin{tabular}{|c|c|c|c|}
\hline & Group A & Group B & Group C \\
\hline Age (years)* & $33.73 \pm 9.56$ & $32.56 \pm 4.97$ & $34.46 \pm 8.57$ \\
\hline Weight $(\mathrm{kg})^{*}$ & $61.73 \pm 8.09$ & $60.87 \pm 7.44$ & $58.63 \pm 7.16$ \\
\hline Height $(\mathrm{cm})^{*}$ & $166.56 \pm 7.14$ & $168.36 \pm 4.43$ & $167.1 \pm 5.93$ \\
\hline BMI $\left(\mathrm{kg} / \mathrm{m}^{2}\right)^{*}$ & $22.41 \pm 2.39$ & $21.73 \pm 2.24$ & $21.27 \pm 1.8$ \\
\hline Gender male/female ${ }^{\#}$ & $17 / 13$ & $12 / 18$ & $14 / 16$ \\
\hline
\end{tabular}

Data expressed as mean \pm SD. *ANOVA test, ${ }^{*}$ Chi-square test. $P>0.05$.

BMI: Body mass index, SD: Standard deviation

Table 2: Time (s) after intubating dose of atracurium for train-of-four count to reach zero

\begin{tabular}{lc}
\hline Group & $\begin{array}{c}\text { Time }(\mathbf{s}) \text { required for TOF count to } \\
\text { reach zero after administration of } \\
\text { intubating dose* }\end{array}$ \\
\hline $\mathrm{A}(0.05 \mathrm{mg} / \mathrm{kg})(n=30)$ & $147.2 \pm 26.72$ \\
$\mathrm{~B}(0.025 \mathrm{mg} / \mathrm{kg})(n=30)$ & $193.2 \pm 25.08$ \\
$\mathrm{C}($ saline $)(n=30)$ & $218 \pm 22.96$ \\
\hline
\end{tabular}

*ANOVA test, Data expressed as mean \pm SD. TOF: Train-of-four, SD: Standard deviation

\begin{tabular}{lccc}
\hline \multicolumn{4}{l}{ Table 3: Intergroup comparison of time (s) after } \\
intubating dose for Train-of-four count to reach zero \\
\hline Group & Comparison group & Mean difference (s) & $\boldsymbol{P}^{\boldsymbol{*}}$ \\
\hline A & B & 46 & $<0.001$ \\
A & C & 71 & $<0.001$ \\
B & C & 25 & 0.041 \\
\hline *Tukey's post hoc test, $P<0.05$ - statistically significant &
\end{tabular}

\begin{tabular}{lccccc}
\hline Table 4: Incidence of adverse effects of priming \\
\hline Group & Diplopia & Ptosis & $\begin{array}{c}\text { Shortness } \\
\text { of breath }\end{array}$ & $\begin{array}{c}\text { Motor } \\
\text { weakness }\end{array}$ & Desaturation \\
\hline A $(n=30)$ & Nil & 2 & Nil & Nil & Nil \\
B $(n=30)$ & Nil & Nil & Nil & Nil & Nil \\
C $(n=30)$ & Nil & Nil & Nil & Nil & Nil \\
\hline
\end{tabular}

\section{Discussion}

The introduction of neuromuscular blockers revolutionized the anesthetic practice, which thereafter underwent a conceptual change. Muscle relaxants are classified into two groups, the depolarizers and nondepolarisers. Suxamethonium is the only depolarizer in use which causes profound muscle relaxation within $60 \mathrm{~s}$ after intravenous administration. Important nondepolarisers in clinical use in our country are vecuronium, atracurium, cisatracurium, and rocuronium. They cause competitive blockade of neuromuscular junction. Most of the nondepolarisers have slower onset of action and are not suitable for rapid control of airway. In 1956, Stenlake et al. synthesized atracurium. Atracurium and its isomers are different from other nondepolarisers because of their organ independent elimination. Atracurium is eliminated predominantly by two pathways: Ester hydrolysis and Hofmann elimination. ${ }^{[6,7]}$
Suxamethonium remains the drug of choice when rapid tracheal intubation is needed. However, there are certain clinical situations wherein suxamethonium is contraindicated. ${ }^{[8]}$ Hence, efforts were made to hasten the onset of action of nondepolarisers. These include priming technique, or the use of high doses of an individual agent or by a combination of different neuromuscular blockers. ${ }^{[5]}$ With higher dose of atracurium $(0.6 \mathrm{mg} / \mathrm{kg})$, onset of action is faster and produced improved conditions for intubation. Higher doses also caused more adverse reactions such as cutaneous flushing, hypotension, and bronchospasm due to histamine release. ${ }^{[9]}$

The priming principle was introduced in 1980s to decrease the time of onset of action of NDMR. With the use of rocuronium this method is somewhat forgotten, although still used. In this method a small, subparalyzing dose of the nondepolarizing agent $\left(20 \%\right.$ of the $\mathrm{ED}_{95}$ or $10 \%$ of the intubating dose) is administered to the patient 2-4 min before the intubating dose of the drug. The mechanism is that when priming dose is administered, it will accelerate the onset of neuromuscular blockade by $30-60 \mathrm{~s}$, thereby facilitating intubation quickly within $90 \mathrm{~s}$ after the intubating dose. ${ }^{[5]}$ Priming dose results in $70 \%-75 \%$ of cholinergic receptor occupancy and subsequent dose administered after the priming dose leads to $>90 \%$ receptor occupancy, which is required for profound muscle relaxation. In reality, intubating conditions after priming do not match those after suxamethonium. Some adverse effects were also encountered while priming had been employed and these are patient discomfort, aspiration risks, difficulty in swallowing/coughing and diplopia. ${ }^{[5,10]}$ This technique is not applicable for those with difficult airway and increased sensitivity to neuromuscular blocking drugs such as myasthenia gravis or those who are taking drugs known to interfere with neuromuscular function.

In 1986, Naguib et al. conducted a study to find out the optimal priming dose of atracurium using wider range of priming dose of atracurium (from $0.04 \mathrm{mg} / \mathrm{kg}$ to $0.09 \mathrm{mg} / \mathrm{kg}$ ) with a priming interval of $3 \mathrm{~min}$. In this study, priming doses in the range of $0.04-0.09 \mathrm{mg} / \mathrm{kg}$ were associated with statistically significant reduction in the TOF ratios, which facilitated rapid tracheal intubation. The optimal priming dose of atracurium was $0.05 \mathrm{mg} / \mathrm{kg}$, which had lesser incidence of adverse effects related to priming. They concluded that optimal priming dose of atracurium was $0.05 \mathrm{mg} / \mathrm{kg}$, which has lesser incidence of adverse effects related to priming. ${ }^{[11]}$ In our study, we used two different priming doses of 0.05 and $0.025 \mathrm{mg} / \mathrm{kg}$ body weight 3 min before intubating dose, which had further helped to reduce the incidence of adverse effects. In our study, time after intubating dose required for TOF count to reach zero was far higher than ideal time of $<90 \mathrm{~s}$ required for rapid sequence intubation. Another study conducted by Naguib et al. regarding rapid tracheal intubation with atracurium and comparing the priming intervals concluded that when priming dose of atracurium is given 3 min before the intubating dose, it can prove as an alternative to succinylcholine for rapid endotracheal intubation. ${ }^{[12]}$ In our study, we have used a 
Duggappa, et al.: Optimal priming dose of atracurium

priming interval of $3 \mathrm{~min}$, which is optimal as found out by several other studies. In a study conducted by Mishra et al. on the effect of priming on intubating conditions produced by atracurium, they found that atracurium in a total dose of $0.7 \mathrm{mg} / \mathrm{kg}$ utilizing priming principle provided excellent intubating conditions at $120 \mathrm{~s}$ after intubating dose. Priming dose of $0.1 \mathrm{mg} / \mathrm{kg}$ (i.e., approximately $14.3 \%$ of total dose) appeared satisfactory without any side effects. ${ }^{[13]}$

Similarly, the priming principle study done by Jaradi et al. regarding shortening the onset time of atracurium for rapid tracheal intubation concluded that priming dose of $0.07 \mathrm{mg} / \mathrm{kg}$ given $3 \mathrm{~min}$ before induction shortens the atracurium onset time to $60 \mathrm{~s}$. However, out of 60 patients, 13 patients had ptosis as adverse effect. ${ }^{[14]}$ In our study of 60 patients who were administered atracurium as priming drug, we encountered two cases of ptosis at the end of $3 \mathrm{~min}$ after priming with $0.05 \mathrm{mg} / \mathrm{kg}$ body weight, with no other side effects. This may have occurred possibly owing to wider inter-individual variations in response to nondepolarizing neuromuscular blockers.

This study has a few limitations. The intubating conditions when priming had been employed were not studied. Laryngeal musculature is known to have different sensitivity to muscle relaxants than the muscles supplied by ulnar nerve. Results with priming dose $>0.05 \mathrm{mg} / \mathrm{kg}$ body weight was not studied owing to the potential for significant muscle weakness, which may be highly distressing for awake patients. The results obtained with atracurium cannot be extrapolated to other NDMR.

\section{Conclusions}

Priming principle employing atracurium reduces the time required for TOF count to reach zero by approximately $71 \mathrm{~s}$ while using $0.05 \mathrm{mg} / \mathrm{kg}$ body weight and by around $25 \mathrm{~s}$ while employing $0.025 \mathrm{mg} / \mathrm{kg}$ body weight, with clinically insignificant incidence of adverse effects.

\section{Financial support and sponsorship}

Nil.

\section{Conflicts of interest}

There are no conflicts of interest.

\section{REFERENCES}

1. Stenlake JB, Waigh RD, Urwin J, Dewar GH, Coker GG. Atracurium: Conception and inception. Br J Anaesth 1983;55 Suppl 1:3S-10S.

2. Stenlake JB, Waigh RD, Dewar GH. Biodegradable neuromuscular blocking agents. Atracurium besylate and related polyalkylene di-esters. Eur J Med Chem 1981;16:515-24.

3. Schwarz S, Ilias W, Lackner F, Mayrhofer O, Foldes FF. Rapid tracheal intubation with vecuronium: The priming principle. Anesthesiology 1985;62:388-91.

4. Mehta MP, Choi W, Gergis SD, Sokoll MD, Adolphson A. Facilitation of rapid sequence endotracheal intubations with divided doses of nondepolarizing neuromuscular blocking drugs. Anesthesiology 1985;62:392-5.

5. Naguib M, Lien CA. Pharmacology of muscle relaxants and their antagonists. In: Miller RD, editor. Miller's Anesthesia. $7^{\text {th }}$ ed. Philadelphia: Churchill Livingstone; 2010. p. 859-911.

6. Stiller RL, Cook DR, Chakravorti S. In vitro degradation of atracurium in human plasma. Br J Anaesth 1985;57:1085-8.

7. Miller RD, Rupp SM, Fisher DM, Cronnelly R, Fahey MR, Sohn YJ, et al. Clinical pharmacology of vecuronium and atracurium. Anesthesiology 1984;61:444-53.

8. Stoelting RK, Hillier SC. Neuromuscular blocking drugs. In: Stoelting RK, Hiller SC, editors. Pharmacology and Physiology in Anesthetic Practice. $4^{\text {th }}$ ed. Philadelphia: Lippincott Williams and Wilkins; 2005. p. 208-50.

9. Mirakhur RK, Lavery GG, Clarke RS, Gibson FM, McAteer E. Atracurium in clinical anaesthesia: Effect of dosage on onset, duration and conditions for tracheal intubation. Anaesthesia 1985;40:801-5.

10. Engbaek J, Howardy-Hansen P, Ording H, Viby-Mogensen J. Precurarization with vecuronium and pancuronium in awake, healthy volunteers: The influence on neuromuscular transmission and pulmonary function. Acta Anaesthesiol Scand 1985;29:117-20.

11. Naguib M, Abdullatif M, Absood GH. The optimal priming dose for atracurium. Can Anaesth Soc J 1986;33:453-7.

12. Naguib M, Gyasi HK, Abdulatif M, Absood GH. Rapid tracheal intubation with atracurium - A comparison of priming intervals. Can Anaesth Soc J 1986;33:150-6.

13. Mishra LD, Nath SS, Bhattacharya DP. Effect of priming on intubating conditions produced by atracurium. Indian $\mathrm{J}$ Anaesth 2003;47:458-62.

14. Jaradi H, Tay KH, Delilkan AE. Shortening the onset time of atracurium for rapid tracheal intubation. Med J Malaysia 1989;44:143-6. 